\begin{tabular}{|c|c|c|c|}
\hline \multirow{2}{*}{$\begin{array}{r}\text { Case Reports in } \\
\text { Gastroenterology }\end{array}$} & \multicolumn{2}{|c|}{ Case Rep Gastroenterol 2016;10:410-416 } & \multirow[b]{2}{*}{$\begin{array}{l}\text { Karger } \\
\text { Open access }\end{array}$} \\
\hline & $\begin{array}{l}\text { DOI: } 10.1159 / 000448068 \\
\text { Publisned ontrne: August 9, } 2016\end{array}$ & $\begin{array}{l}\text { (c) } 2016 \text { The Author(s) } \\
\text { Published by S. Karger AG, Basel } \\
\text { www.karger.com/crg }\end{array}$ & \\
\hline & $\begin{array}{l}\text { This article is licensed under } \\
\text { International License (CC BY-N } \\
\text { Usage and distribution for comm }\end{array}$ & $\begin{array}{l}\text { nons Attribution-NonCommer } \\
\text { ger.com/Services/OpenAccessLi } \\
\text { uires written permission. }\end{array}$ & \\
\hline
\end{tabular}

\title{
Acute Cholecystitis with Significantly Elevated Levels of Serum Carbohydrate Antigen 19-9
}

\author{
Shuji Akimoto ${ }^{a}$ d Masataka Banshodani $^{b} \quad$ Masahiro Nishihara ${ }^{a}$ \\ Junko Nambu ${ }^{a}$ Yasuo Kawaguchi ${ }^{a}$ Fumio Shimamoto ${ }^{c}$ Kiyohiko Dohi ${ }^{a}$ \\ Keizo Sugino ${ }^{a}$ Hideki Ohdan $^{d}$ \\ ${ }^{a}$ Department of Surgery, Akane-Foundation, Tsuchiya General Hospital, Hiroshima, Japan; \\ ${ }^{b}$ Department of Artificial Organs, Akane-Foundation, Tsuchiya General Hospital, \\ Hiroshima, Japan; 'Department of Pathology, Faculty of Human Culture and Science, \\ Prefectural University of Hiroshima, Hiroshima, Japan; ${ }^{d}$ Department of Gastroenterological \\ and Transplant Surgery, Applied Life Sciences, Institution of Biomedical and Health \\ Sciences, Hiroshima University, Hiroshima, Japan
}

\section{Keywords}

Acute cholecystitis · Carbohydrate antigen 19-9 · High elevation · Positron emission tomography-computed tomography

\begin{abstract}
Serum carbohydrate antigen 19-9 (CA 19-9), a marker of malignant tumors, is generally slightly elevated in benign conditions. We report a case of acute cholecystitis with a significantly elevated level of serum CA $19-9$ based on positron emission tomography (PET)computed tomography (CT) findings. A 65-year-old woman presented with abdominal pain and fever. A CT image revealed an enlarged gallbladder without tumor shadows. The Creactive protein (CRP) level was elevated to $7.66 \mathrm{mg} / \mathrm{dl}$. Moreover, the serum CA 19-9 level was significantly elevated to $19,392 \mathrm{U} / \mathrm{ml}$. We started antibiotic treatment, because we suspected acute cholecystitis, but still, we could not ignore the possible presence of malignant tumors. After 11 days of antibiotic treatment, serum CRP and CA 19-9 levels decreased to $0.11 \mathrm{mg} / \mathrm{dl}$ and $1,049 \mathrm{U} / \mathrm{ml}$, respectively. There was an accumulation of fluorine 18-labeled fluorodeoxyglucose (maximum standardized uptake value, 9.3) without tumor shadows in the
\end{abstract}


liver, near the gallbladder, on the PET-CT examination. We considered the possibility that the inflammation had spread from the gallbladder to the liver, made a diagnosis of acute cholecystitis, and performed a cholecystectomy 33 days after treatment initiation. The serum CA 19-9 level decreased to $45 \mathrm{U} / \mathrm{ml}$ after the surgery. One year after the surgery, the patient was alive, and the serum CA 19-9 level was $34 \mathrm{U} / \mathrm{ml}$. Acute cholecystitis with a significantly high elevation of the serum CA 19-9 level is rare. In such cases, it is important to confirm the change in the serum CA 19-9 level over time after antibiotic treatment and perform imaging studies to distinguish between inflammation and malignancy.

(C) 2016 The Author(s)

Published by S. Karger AG, Basel

\section{Introduction}

Carbohydrate antigen 19-9 (CA 19-9), which was first described by Koprowski et al. [1] in 1979, is produced in the biliary and pancreatic ductal cells. A CA 19-9 level of $<37 \mathrm{U} / \mathrm{ml}$ is considered normal [2]. Because CA 19-9 can be detected in gastrointestinal and nongastrointestinal cancers [1, 3], especially pancreatic and biliary cancers, it is a useful serum biomarker for these cancers [2].

Serum CA 19-9 levels can be elevated in many benign conditions, including cholangitis, cholestasis, benign obstructive jaundice, liver cirrhosis, hepatitis, liver cyst, liver abscess, polycystic liver disease, bronchitis, congestive heart disease, diverticulitis, Hashimoto's thyroiditis, ovarian cyst, renal cyst, and rheumatoid arthritis [4-7]. However, the elevation of CA 19-9 levels in these conditions is usually mild [2]. In a patient who presented with acute cholecystitis with gallstones, a high level of serum CA 19-9 was reported, but the value was $<5,000 \mathrm{U} / \mathrm{ml}[8]$.

Fluorine 18-labeled fluorodeoxyglucose (18F-FDG) positron emission tomography (PET) is an effective diagnostic oncologic imaging technique [9]. However, ${ }^{18 F-F D G ~ P E T ~ d e m o n-~}$ strates low specificity for the differentiation of malignant tumors from inflammatory lesions [10].

We report a case of acute cholecystitis with a significantly elevated level of serum CA 199 with a diagnosis based on PET-computed tomography (CT) findings.

\section{Case Report}

A 65-year-old woman was admitted for evaluation of epigastric pain and fever $\left(38.5^{\circ} \mathrm{C}\right)$; these symptoms had begun 7 and 4 days, respectively, prior to admission. The laboratory data of the patient during hospitalization were as follows: white blood cell count of $6,100 / \mu \mathrm{l}$

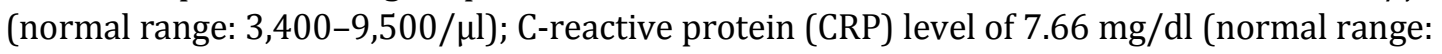
$<0.5 \mathrm{mg} / \mathrm{dl}$ ); total bilirubin level of $0.5 \mathrm{mg} / \mathrm{dl}$ (normal range: $0.2-1.0 \mathrm{mg} / \mathrm{dl}$ ); direct bilirubin level of $0.1 \mathrm{mg} / \mathrm{dl}$ (normal range: $<0.4 \mathrm{mg} / \mathrm{dl}$ ); aspartate aminotransferase level of $19 \mathrm{IU} / \mathrm{l}$ (normal range: 8-38 IU/l); alanine aminotransferase level of $18 \mathrm{IU} / \mathrm{l}$ (normal range: 4-44 $\mathrm{IU} / \mathrm{l}$ ), and alkaline phosphatase level of $326 \mathrm{IU} / \mathrm{l}$ (normal range: 104-338 IU/l). The serum carcinoembryonic antigen (CEA) level was $1.9 \mathrm{ng} / \mathrm{ml}$ (normal range: $<5.0 \mathrm{ng} / \mathrm{ml}$ ), while the serum CA 19-9 level was significantly elevated to $19,392 \mathrm{U} / \mathrm{ml}$ (normal range: $<37 \mathrm{U} / \mathrm{ml}$ ). Ultrasonography revealed biliary sludge, a gallstone with a $17-\mathrm{mm}$ diameter, and a thickened wall of the gallbladder (fig. 1a). Contrast-enhanced CT revealed the enlargement and thickened wall of the gallbladder with the gallstone in the neck of the gallbladder (fig. 1b-d). 


\section{Case Reports in Gastroenterology}

Case Rep Gastroenterol 2016;10:410-416 $10.1159 / 000448068$ (C) 2016 The Author(s). Published by S. Karger AG, Basel www.karger.com/crg

Akimoto et al:: Acute Cholecystitis with Significantly Elevated Levels of Serum Carbohydrate Antigen 19-9

First, we started antibiotic treatment using levofloxacin, because we suspected acute cholecystitis; however, we could not deny the possibility of the presence of malignant tumors. After 11 days of antibiotic treatment, the symptoms disappeared and serum CRP and CA 199 levels decreased to $0.11 \mathrm{mg} / \mathrm{dl}$ and $1,049 \mathrm{U} / \mathrm{ml}$, respectively. There was an accumulation of ${ }^{18} \mathrm{~F}-\mathrm{FDG}$ [maximum standardized uptake value ( $\left(\mathrm{SUV}_{\max }\right), 9.3$ ] without tumor shadows in the medial segment of the liver near the fundus of the gallbladder on the ${ }^{18}$ F-FDG PET-CT examination of the whole body 28 days after antibiotic treatment initiation (fig. 2). We considered the possibility that the inflammation had spread from the fundus of the gallbladder to the medial segment of the liver.

Accordingly, the patient was regarded as having acute cholecystitis with a gallstone. A cholecystectomy was performed 33 days after antibiotic treatment initiation. Surgery revealed that the gallbladder had severely adhered to the omentum and duodenum, and that the gallstone $(17 \mathrm{~mm})$ was incarcerated in the neck of the gallbladder. Macroscopically, the gallbladder was edematous and grossly thickened (fig. 3a). On pathological examination (HE), inflammatory cells spread to all layers of the gallbladder wall. However, there were no findings suggesting malignancy (fig. 3b). On immunostaining examination using a CA 19-9 monoclonal antibody, the cytoplasm of the mucosal epithelium was well-stained with CA 199 in the gallbladder wall (fig. 3c, d).

The serum CA 19-9 level decreased to $45 \mathrm{U} / \mathrm{ml} 21$ days after the surgery. One year after the surgery, the patient was alive, and her serum CA 19-9 level was $34 \mathrm{U} / \mathrm{ml}$ (within the normal range).

\section{Discussion}

CA 19-9, a glycosphingolipid of the Lewis blood group, has been used as a serum tumor marker for malignancies of the gastrointestinal tract, especially of the pancreas and biliary tract [2]. When serum CA 19-9 levels are $>1,000 \mathrm{U} / \mathrm{ml}$, patients usually have gastrointestinal cancers [2]. However, a previous report showed that only $4.7 \%$ of patients with acute cholangitis or cholestasis had a serum CA 19-9 level $>1,000 \mathrm{U} / \mathrm{ml}$ [11]. CA 19-9 is produced in the biliary and pancreatic ductal cells; however, the mechanisms of CA 19-9 elevation remain unclear [12]. In this case, the serum CA 19-9 level was significantly elevated in spite of acute cholecystitis $(19,392 \mathrm{U} / \mathrm{ml})$. We considered the following mechanisms: first, bile flow may be blocked due to cystic duct obstruction by gallstones and biliary sludge. Then, the epithelial cells of the gallbladder wall may be impaired by the blocked bile flow, increased internal pressure of the gallbladder, and inflammatory conditions. Subsequently, production of CA 19-9 in the epithelium of the gallbladder may be increased, and increased CA 19-9 may leak into the blood circulation.

Occasionally, it is very difficult to distinguish between malignant and benign diseases in patients with significantly elevated levels of serum CA 19-9. For these patients, the diagnosis must be evaluated carefully depending on the conditions [11]. In our case, the serum CA 199 level decreased after the antibiotic treatment, and the serum CEA level was within a normal range at the onset of the symptoms. We suggest the following methods to distinguish between malignant and benign diseases in patients with significantly elevated levels of serum CA 19-9: confirm the change in serum CA 19-9 and CRP levels over time after antibiotic treatment and perform imaging studies, confirm the serum CEA level at the onset of symptoms, or use operative rapid pathological diagnosis methods to prevent excessive surgeries. 
18F-FDG PET is a diagnostic technique using glucose metabolism differences between benign and malignant lesions [9]. 18F-FDG PET-CT is a combination of functional and anatomic imaging and a highly accurate diagnostic examination [13]. However, 18 F-FDG accumulates not only in tumor cells but also in inflammatory cells [10]. A previous report demonstrated that delayed ${ }^{18} \mathrm{~F}$-FDG PET was more helpful than early ${ }^{18} \mathrm{~F}$-FDG PET in the evaluation of malignancy [14], and the mean values of early and delayed SUV of ${ }^{18}$ F-FDG PET in gallbladder carcinoma were 7.35 and 9.30, respectively. In this case, SUV $\max$ was 9.3 and was similar to the delayed SUV of the gallbladder carcinoma in the previous report. Therefore, it was difficult to rely solely on imaging studies to distinguish between inflammation and malignancy. However, our report is valuable in that no previous reports presented PET-CT findings of acute cholecystitis with significantly elevated levels of serum CA 19-9.

\section{Conclusion}

Acute cholecystitis with a significantly elevated level of serum CA 19-9 $(>10,000 \mathrm{U} / \mathrm{ml})$ is rare. In such a case, it is important to confirm the change in serum CA 19-9 level over time after antibiotic treatment and perform imaging studies to distinguish between inflammation and malignancy.

\section{Statement of Ethics}

This study was approved by our institutional review board for human investigations and performed according to the principles of the Declaration of Helsinki. Written informed consent for the procedure and publication of this case report and any accompanying images was obtained from the patient

\section{Disclosure Statement}

The authors declare no conflicts of interest or funding interests in connection with the publication of this article. No external funding was used to perform this investigation.

\section{References}

1 Koprowski H, Steplewski Z, Mitchell K, Herlyn M, Herlyn D, Fuhrer P: Colorectal carcinoma antigens detected by hybridoma antibodies. Somatic Cell Genet 1979;5:957-971.

2 Steinberg W: The clinical utility of the CA 19-9 tumor-associated antigen. Am J Gastroenterol 1990;85:350-355.

3 Koprowski H, Herlyn M, Steplewski Z, Sears HF: Specific antigen in serum of patients with colon carcinoma. Science 1981;212:53-55.

4 Albert MB, Steinberg WM, Henry JP: Elevated serum levels of tumor marker CA19-9 in acute cholangitis. Dig Dis Sci 1988;33:1223-1225.

5 Turtel PS, Kreel I, Israel J, Frager D, Berman D: Elevated CA 19-9 in a case of Mirizzi's syndrome. Am J Gastroenterol 1992;87:355-357.

6 Mann DV, Edwards R, Ho S, Lau WY, Glazer G: Elevated tumor marker CA19-9: clinical interpretation and influence of obstructive jaundice. Eur J Surg Oncol 2000;26:474-479.

7 Ballehaninna UK, Chamberlain RS: The clinical utility of serum CA 19-9 in the diagnosis, prognosis and management of pancreatic adenocarcinoma: an evidence based appraisal. J Gastrointest Oncol 2012;3:105-119. 


\section{Case Reports in Gastroenterology}

\begin{tabular}{l|l}
\hline Case Rep Gastroenterol 2016;10:410-416 \\
\hline $10.1159 / 000448068$ & $\begin{array}{l}\text { @ 2016 The Author(s). Published by S. Karger AG, Basel } \\
\text { www.karger.com/crg }\end{array}$ \\
\hline
\end{tabular}

Akimoto et al:: Acute Cholecystitis with Significantly Elevated Levels of Serum Carbohydrate Antigen 19-9

8 Murohisa T, Sugaya H, Tetsuka I, Suzuki T, Harada T: A case of common bile duct stone with cholangitis presenting an extraordinarily high serum CA19-9 value. Intern Med 1992;31:516-520.

$>9$ Coleman RE: Clinical PET in oncology. Clin Positron Imaging 1998;1:15-30.

-10 Kubota R, Yamada S, Kubota K, Ishiwata K, Tamahashi N, Ido T: Intratumoral distribution of fluorine18-fluorodeoxyglucose in vivo: high accumulation in macrophages and granulation tissues studied by microautoradiography. J Nucl Med 1992;33:1972-1980.

11 Kim HJ, Kim MH, Myung SJ, Lim BC, Park ET, Yoo KS, Seo DW, Lee SK, Min YI: A new strategy for the application of CA19-9 in the differentiation of pancreaticobiliary cancer: analysis using a receiver operating characteristic curve. Am J Gastroenterol 1999;94:1941-1946.

12 Arends JW, Verstynen C, Bosman FT, Hilgers J, Steplewski Z: Distribution of monoclonal antibodydefined monosialoganglioside in normal and cancerous human tissues: an immunoperoxidase study. Hybridoma 1983;2:219-229.

13 Zhang M, Jiang X, Zhang M, Xu H, Zhai G, Li B: The role of 18F-FDG PET/CT in the evaluation of ascites of undetermined origin. J Nucl Med 2009;50:506-512.

14 Nishiyama Y, Yamamoto Y, Fukunaga K, Kimura N, Miki A, Sasakawa Y, Wakabayashi H, Satoh K, Ohkawa M: Dual-time-point ${ }^{18}$ F-FDG PET for the evaluation of gallbladder carcinoma. J Nucl Med 2006;47:633-638.
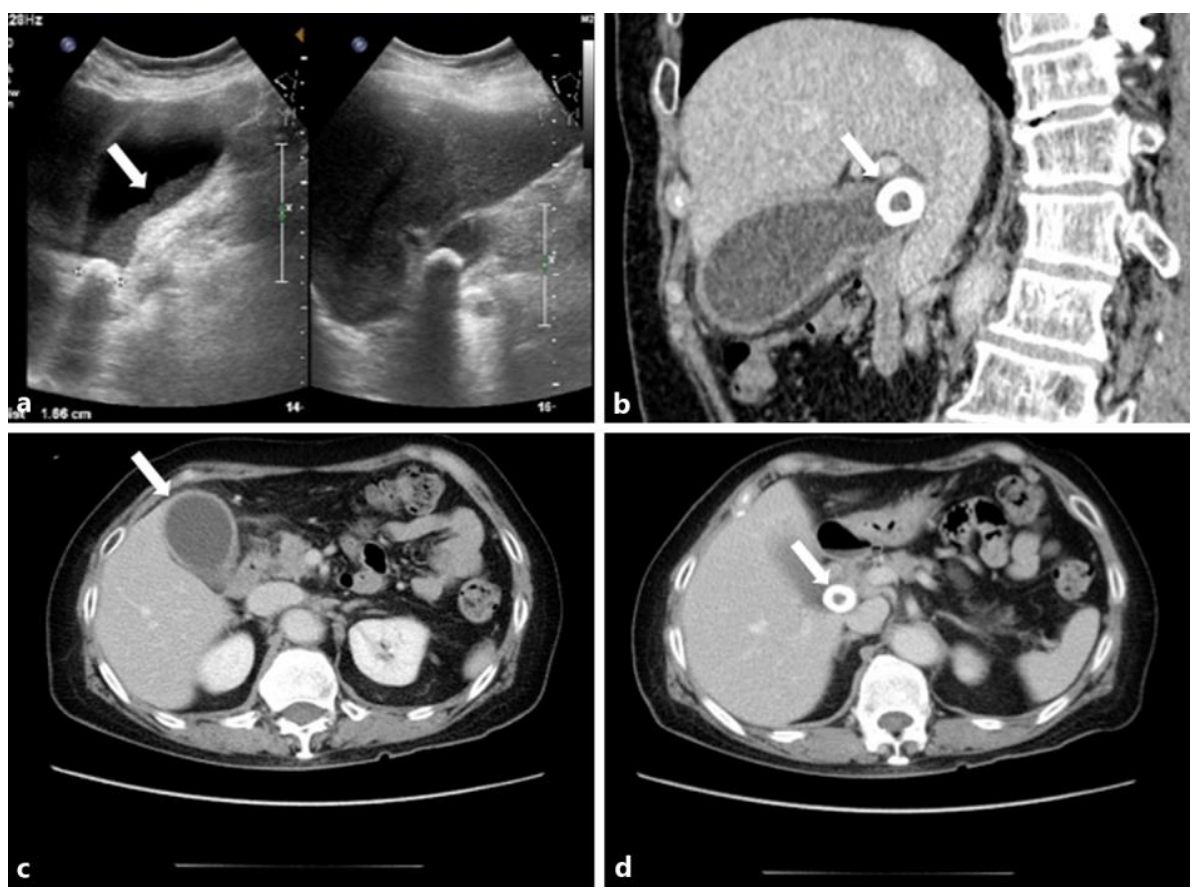

Fig. 1. Ultrasonography and CT images. a Ultrasonography revealing biliary sludge, a gallstone with a diameter of $17 \mathrm{~mm}$, and thickened wall of the gallbladder. $\mathbf{b}$ Contrast-enhanced CT scan in the coronal view revealing a gallstone in the neck of the gallbladder (white arrow). $\mathbf{c}, \mathbf{d}$ Contrast-enhanced CT scans in horizontal views revealing the enlargement and thickened wall of the gallbladder (white arrow) (c) with the gallstone in the neck of gallbladder (white arrow) (d). 


\begin{tabular}{|c|c|c|}
\hline \multirow{3}{*}{$\begin{array}{r}\text { Case Reports in } \\
\text { Gastroenterology }\end{array}$} & \multirow{2}{*}{\multicolumn{2}{|c|}{ Case Rep Gastroenterol 2016;10:410-416 }} \\
\hline & & \\
\hline & $10.1159 / 000448068$ & $\begin{array}{l}\text { ( } 2016 \text { The Author(s). Published by S. Karger AG, Basel } \\
\text { www.karger.com/crg }\end{array}$ \\
\hline & $\begin{array}{l}\text { Akimoto et al.: Ac } \\
\text { Carbohydrate Antige }\end{array}$ & ystitis with Significantly Elevated Levels of Serum \\
\hline
\end{tabular}

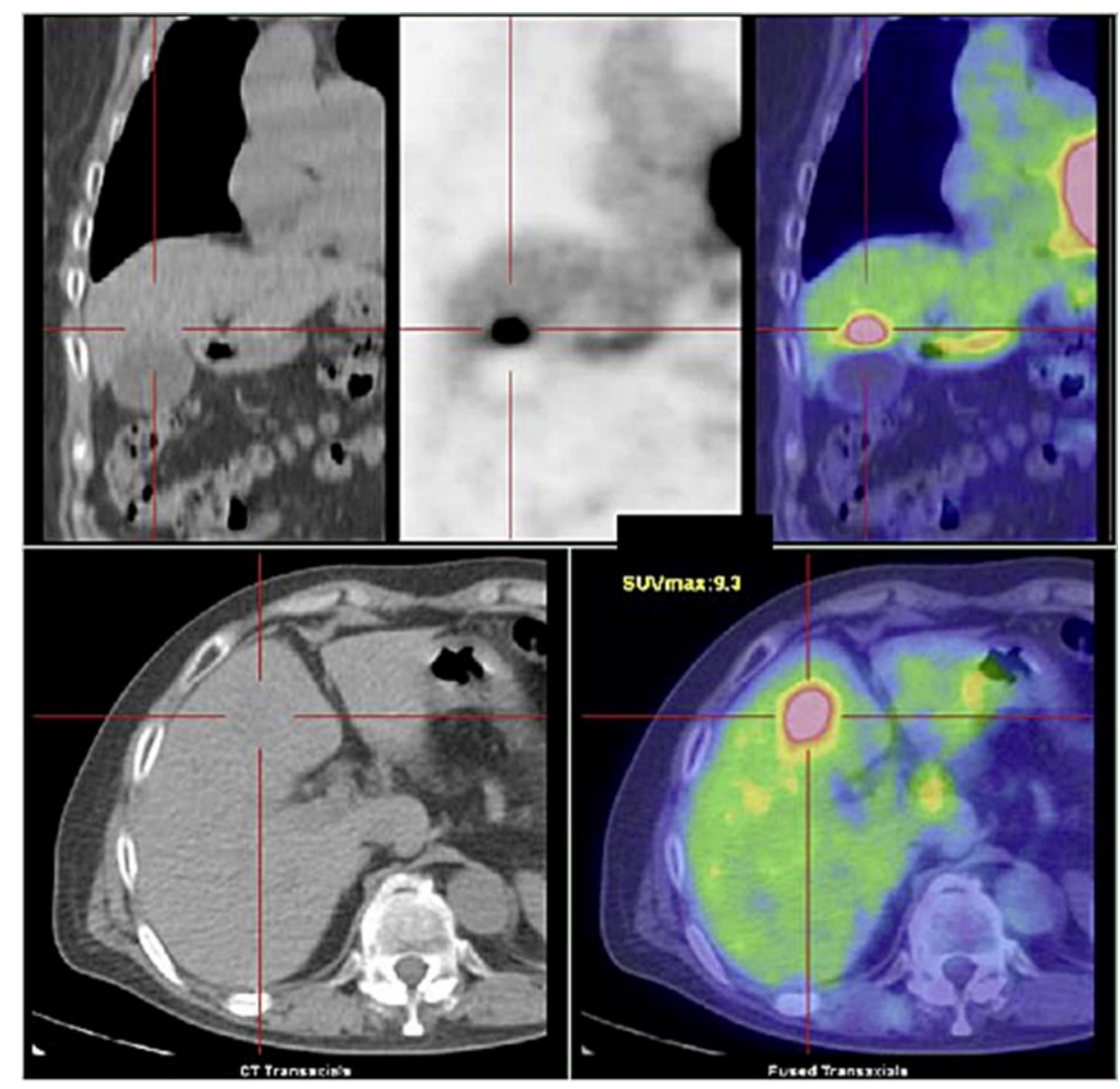

Fig. 2. ${ }^{18 F-F D G ~ P E T-C T ~ i m a g e s ~ a n d ~ a c c u m u l a t i o n ~ o f ~} 18$ F-FDG (SUV $\left.\max , 9.3\right)$ without tumor shadows in the medial segment of the liver near the fundus of the gallbladder. 

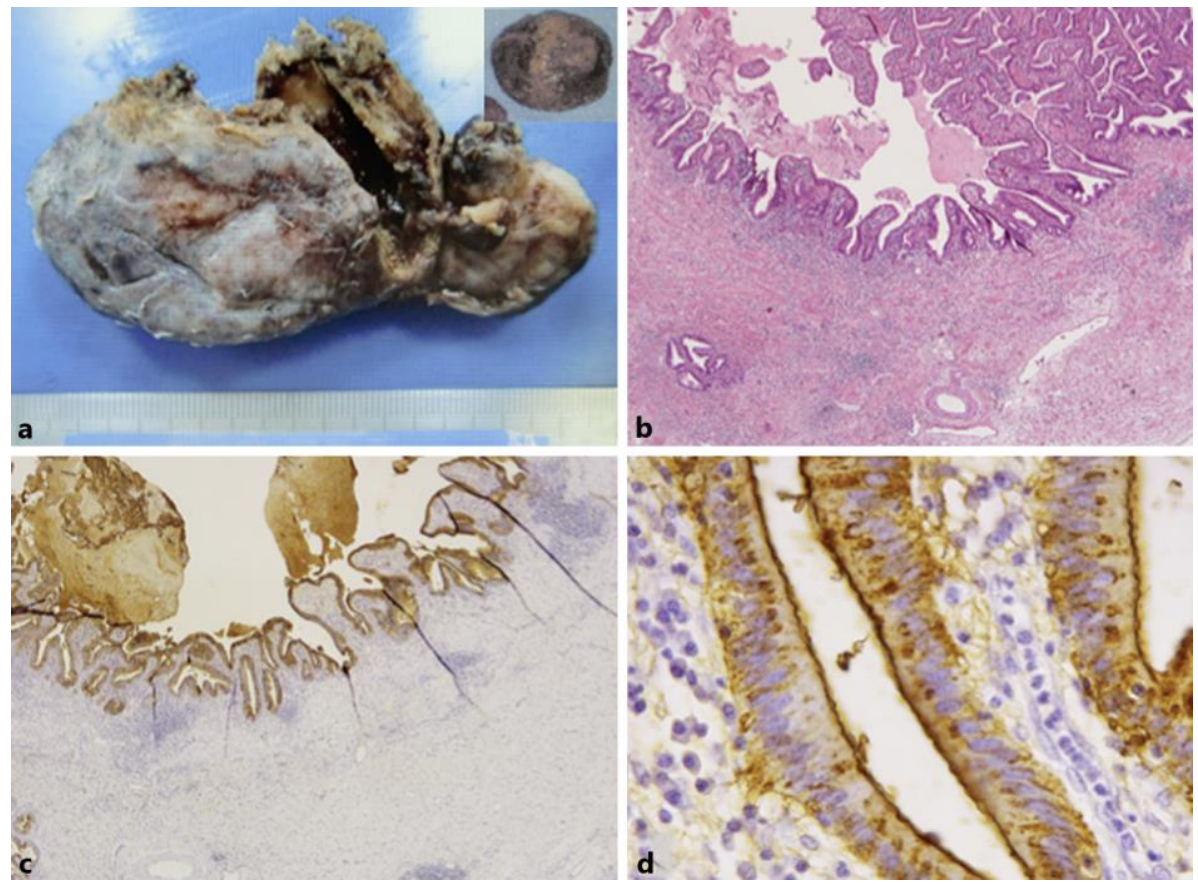

Fig. 3. Pathological tissue images. a Macroscopically, the gallbladder is edematous and grossly thickened. b Pathological examination $(\mathrm{HE}, \times 40)$ shows that inflammatory cells had spread to all layers of the gallbladder wall. c, d On immunostaining examination using CA 19-9 monoclonal antibody, the cytoplasm of the mucosal epithelium was well-stained with CA 19-9 in the gallbladder wall. Low-power ( $\times 40)(\mathrm{c})$ and high-power $(\times 400)(d)$ fields. 